DAI Jinhua. 2018. After the Post-Cold War: The Future of Chinese History. Durham, NC: Duke University Press.

Book review

Jessica Yeung

CpenEdition

Journals

Electronic version

URL: http://journals.openedition.org/chinaperspectives/9558

DOI: 10.4000/chinaperspectives.9558

ISSN: 1996-4617

Publisher

Centre d'étude français sur la Chine contemporaine

Printed version

Date of publication: 1 September 2019

Number of pages: $72-73$

ISSN: 2070-3449

Electronic reference

Jessica Yeung, «DAI Jinhua. 2018. After the Post-Cold War: The Future of Chinese History. Durham, NC: Duke University Press. », China Perspectives [Online], 2019-3 | 2019, Online since 01 September 2019, connection on 19 December 2020. URL : http://journals.openedition.org/chinaperspectives/9558 ; DOI : https://doi.org/10.4000/chinaperspectives.9558

This text was automatically generated on 19 December 2020 .

(c) All rights reserved 


\section{DAI Jinhua. 2018. After the Post-Cold War: The Future of Chinese History. Durham, NC: Duke University Press.}

Book review

Jessica Yeung

This book is the second volume in the book series Sinotheory. The series publishes theoretical writings about China written or translated into English, as well as English translations of Chinese literary writings with theoretical concerns. In recent years there have been a good number of English translations of Chinese research writings published by international academic publishers. This trend is definitely a positive development, as it facilitates various indigenous Chinese academic voices to better represent themselves in the global era, and various Chinese intellectual debates to be heard across language barriers. However, the quality of these writings and their translations vary drastically. This volume is one of the best publications of its kind,

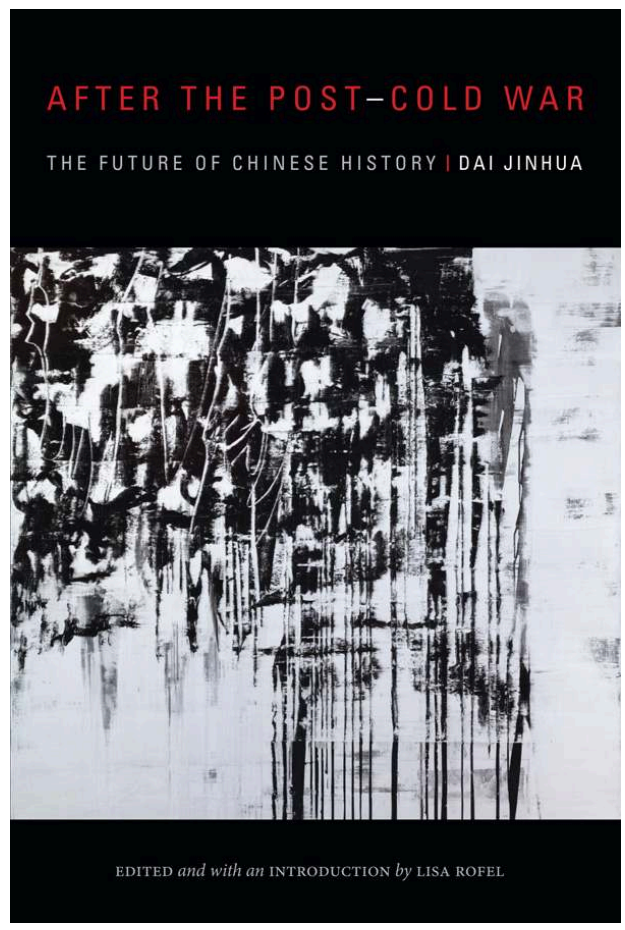
not only because of the brilliance of the original essays, but also because of the excellent translation and editing that come across as judicious as one reads it. Dai is one of contemporary China's most influential academic and public intellectuals. Her signature critical vigour and stylistic sharpness is recognisable in all her writings, and in this volume it is rendered in equally rigorous English critical idiom. Although the 
essays are handled by a team of translators, the consistency of the critical trajectory running through the essays is meticulously preserved.

The author's "Introduction" brings in two starting points for the discussions in the book: China's history as a Marxist state; and the world in the post-Cold War era. The central questions she asks are: Does China offer an alternative (to the Western capitalist) model to modernisation? And what does the Chinese model really mean? To prepare for the discussions to follow, she provides a detailed account of how China has transformed from a revolutionary state to a capitalist one, paying attention to the ideological trends that have responded to landmark historical events. This account has made the complicated situation of China much less opaque to its readers. Furthermore, the changes that have occurred in China are understood in the book as being within the context of world history. Moreover, sufficient focus is put on explaining what China's transformation says about the world at large. Works about China's transformation abound, but such an intrinsically global perspective is unique to this study.

Each of the subsequent six chapters discusses how her film case studies attempt to deal with China's twentieth century history. In Chapter One, Dai identifies "the human" as a trope used by Chinese intellectuals since the May Fourth generation to construct their relations with the world. Lu Chuan's 陸川 Nanjing! Nanjing! (南京! 南京! or City of Life and Death, 2009, 133 min.) shows a desire of the Chinese middle-class to identify themselves as the universal human in the backdrop of historical trauma, although this "universal human" lacks the critical dimension of the May Fourth ideal. However, without reconciliation in reality with Japan regarding the massacre, the treatment of the historical event in the film Nanjing! Nanjing! becomes awkward. The result is a forgetful glossing over of the historical event, which Dai sees as symptomatic of China's new place in the post-Cold War world in which it continues to seek new relations with Japan conforming to the capitalist order.

In Chapter Two, Dai examines the meme of tianxia (天下) (heaven above and everything below) in different intellectual traditions, and especially as a signifier in Zhang Yimou's 張藝謀 2003 film Hero (英雄 Yingxiong, 2002, 99 min.). She concludes that the idea of tianxia in the film is associated with power and hegemony, and the film shows the cynical attitude of accepting and working with power to bring about a new world order when resistance is perceived as ineffective. Dai also identifies a further layer of signification of tianxia in the film: for Fifth Generation directors, including Zhang Yimou, tianxia also conjures the memory of Red Guards' imagination of an international Communist revolution, which renders its present signification in the film more ironic. Yet, all these layers of meaning are lost to non-Chinese audiences. The film's international box office success therefore only reveals that China as a signifier has begun operating in the international cultural consumerist market.

In Chapter Three, Dai compares the space-time trope in Jia Zhangke's 賈樟柯 Still Life (三峽好人 Sanxia hao ren, 2006, 108 min.) with that of Fifth Generation films. In the latter, progress and modernity are seen as something constantly deferred by the vast space-history of the Chinese culture, while in Jia's depiction of the Three Gorges, modernity is achieved at the expense of people's livelihood and local history. But the film's success with European film festivals prompts Dai to ask: if non-Western auteur directors are dependent on those festivals to further their careers, would they not conform to the psychological type of dissident artist of the non-West that the West favours? As a result, is there really room for non-Western auteur directors to develop 
their own logic and aesthetic? Dai concludes that, like the rural poverty depicted in Still Life that cannot be solved by capitalist development, which is in fact part of the cause of that poverty, it is highly doubtful that Jia's success could change the cultural marginalisation of non-Western cultures in the context of globalisation.

Chapter Four offers a reading of Zhang Meng's 張猛 comic-tragic film The Piano in a Factory (鋼的琴 : 一個時代的輓歌, Gang de qin: yi ge shidai de wange, 2010, $107 \mathrm{~min}$.), which depicts the lost class of workers in China's new economic order in the Reform Era. Dai notes critics' comparison to films made in Eastern Europe, where a similar situation has been experienced, and considers the film a valuable documentation of the rarely expressed sentiments of the people left behind in the post-Cold War world order.

Chapter Five discusses the genre of spy movies. Dai observes that in the post-Cold War world, spy movies no longer attract audiences with a clear-cut friend-foe binarism, but rather with the anxiety resulting from the ambivalent identity of the spy as individual. This is as true in the Hong Kong movie Infernal Affairs (無間道 Wu jian dao, 2002, 101 min.) as in other Chinese and Western films of the genre. Subjectivity has become the site of inquiry, and Dai understands this as a sign of society transitioning out of the Cold War period.

This line of inquiry is continued in Chapter Six with Ang Lee's 李安 film Lust, Caution (色，戒, Se, Jie, 2007, $158 \mathrm{~min}$.). The moral ambiguity of the protagonist prompts an interesting comparison with the political position of the author of the original novel, Eileen Chang, and even more so with the film director Ang Lee's status as a member of the Chinese diaspora whose identity transcends loyalty and patriotism. The individual's subjectivity takes over as the focal point of concern. The film's distribution in China in 2007 sparked controversy, but Dai observes that the debate was a contention between humanism and nationalism, both lying within the ideological confines of capitalism, rather than that of ideological confrontation that once characterised the Cold War worldview. In China, that worldview has been replaced by the ideology of the nation state predicated on capital.

In the final chapter Dai discusses in general how post-Cold War Chinese films respond to the new historical narratives of the era. She contends that, as capitalism has won without fighting a war at the end of the twentieth century, and attempts for world order alternatives to capitalism have reached a dead end, alternative historical narratives can no longer continue. That complex historical memory of seeking alternatives to capitalism is suppressed in subsequent historical narratives, as exemplified in many German films in the post-Cold War period, emphasising forgetfulness and reconciliation. At this time in history China finds itself in the awkward position of being the biggest socialist country but one that is fast heading towards capitalism. The new hegemonic order requires the ideology of revolution to be forgotten, and it is therefore replaced by the ideology of the nation state. Many works of popular culture and big-ticket films contribute to the project of forgetting Cold War history and the part China has played in it. As a theoretical concern, Dai asks whether we have the theoretical tools to critique this new worldview and its corresponding works: if all existing theoretical tools have been spawned by the Cold War worldview, how do we do theory in the post-Cold War era?

These chapters are followed by an edited script of an interview with Dai Jinhua by the book editor Lisa Rofel to explain the development of her theoretical trajectory. Dai's experience of becoming aware of gender, class, and environmental problems in the 
post-Cultural Revolution period could be read not just as a personal story, but also as a testimony of the transformation of political consciousness amongst Chinese intellectuals of her generation.

\section{AUTHOR}

\section{JESSICA YEUNG}

Jessica Yeung is Associate Professor in the Department of Translation, Interpreting, and Intercultural Studies at Hong Kong Baptist University.jyeung@hkbu.edu.hk 